\title{
Towards Maturity in 1 Peter: Freedom, Holiness, Immortality
}

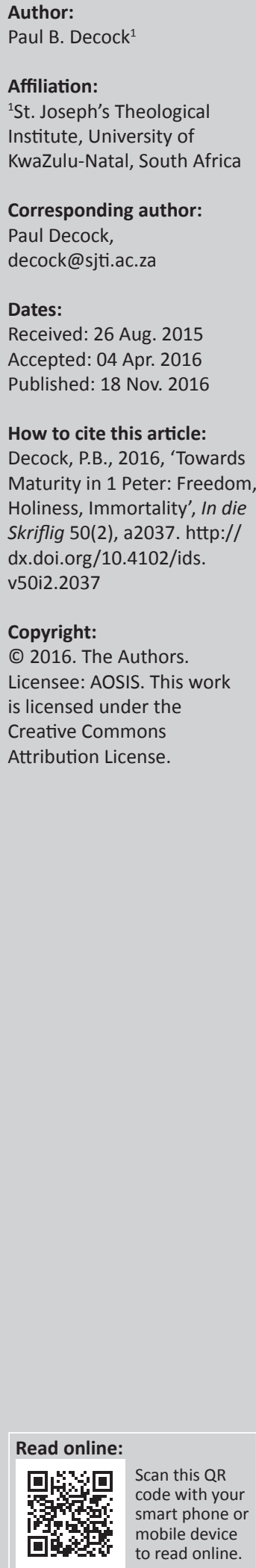

Growth towards maturity is dependent on the presence of freedom, holiness and immortality. These are presented as divine qualities that are utterly lacking in human beings. However, while human beings are ignorant and weak, sinful and mortal the addressees of 1 Peter $^{1}$ are reminded that they have also been begotten anew by the imperishable seed of God's Word, the Good News of Jesus Christ in order to share immortal life. This article looks first at human beings who as God's creatures are 'flesh', but are also enabled to acknowledge their 'fleshly' state, to appreciate ('desire' and 'taste') (2:2-3) the Gospel and to submit to God. The second part considers the saving role of Christ as the powerful yet rejected 'stone' placed and offered by God as the model and means to transcend the 'flesh' in the flesh (4:1-2). A final part focuses on the new birth and the growth process in which the fleshly desires and ways of living give way to a manner of life, which is a witness to God's saving power.

\section{Introduction}

We can find at least three sets of contrasting pairs in 1 Peter, each one of them characterising on the one hand the initial human condition, and on the other hand the divine life. First of all, there is the contrast between human mortality and divine immortality $(1: 24){ }_{i}^{2}$ next there is the contrast between human evil and divine holiness $(1: 14-16){ }^{3}$ and, finally, in $2: 16^{4}$ there is the contrast between enslavement and freedom. Freedom is only mentioned in this one verse, but the challenge to live a life of freedom as elaborated in the different exhortatory sections underlies the whole letter. This article will attempt to understand 1 Peter's approach to growth, responsibility and freedom in light of the first three centuries of Christianity. On the one hand, it was taken for granted that human beings are responsible for their actions and will be judged by God according to their actions (1:17; 2:23; 4:5; compare Mt 25:31-46). On the other hand, human freedom, unlike divine freedom, is the freedom of a creature, a freedom under God. True human freedom is therefore service of God while false freedom is enslavement to evil (2:16). The goal of maturity, ${ }^{5}$ and eventually of salvation (2:2), is a move from false freedom to true freedom, which involves a move from sinfulness to holiness and eventually from mortality to immortality. Maturity and the state of future salvation are meant to be a reflection of God's own perfection (1:15-16). That perfection has been embodied in the life, death and resurrection of Jesus Christ, and is held before the addressees as the basis of their salvation and as the model to be followed, as for instance in 2:21-24.

True freedom therefore manifests itself in 'respecting all, loving the brotherhood, fearing God and honouring the king' (1:17). According to Philo (Prob. 45-46) ${ }^{6}$ such freedom requires 'right reason' or 'right thinking' to which one then submits by implementing it in one's conduct. In this light we can understand the Évvotav in 4:1, which here means not merely theoretical knowledge, but 'intention or disposition in the sphere of moral action' (Achtemeier 1996:277) or even 'resolve' (Michaels 1988:225). The Good News as a whole provides that 'right reason', which 1.All references to 1 Peter will be indicated only by chapters and verses.

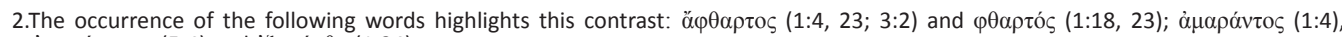

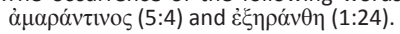

3.There is the contrast between the desires of the flesh fighting against the soul $(2: 11)$ and the challenge to desire ardently the milk of God's Word (2:2). Parallel to this set of pairs is also that of 'futile conduct' (1:18) contrasted with 'good or holy conduct' $(1: 15 ; 2: 12$; $3: 2,16)$.

4.According to F.S. Jones (1992:858), 'While this passage [2:16] might seem to recall Gal 5:13 and 2 Cor 3:15-18, Paul never advances the paradox that one is free while being a slave of God, whereas this idea is found in other writings (Sen. Vit. Beat. 15:7; Apul. Met. 11:15; Philo Quod Omn.20; ...).'

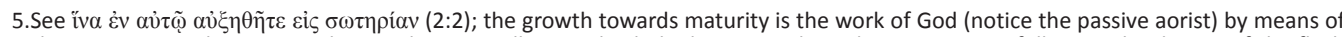
their passionate devotion to the Good News. Following this holy desire stands in clear contrast to following the desires of the flesh $(1: 14 ; 2: 11 ; 4: 2-3)$.

6.I have followed P.H. Alexander et al. (1999), for the abbreviations of the biblical books, the works of Philo and the Church Fathers. 
delivers from enslaving ignorance $(1: 14 ; 2: 15)$. 1 Peter aims at contributing to the development of the right way of thinking and freedom as he reminds his addressees of their situation in the whole of God's plan of salvation. ${ }^{7}$ This knowledge of faith opens up hopeful and joyful perspectives so that the believers can be filled with love for Christ (1:8-9) and with strength to resist the evil one (5:9). Furthermore, this knowledge provides guidance for life in this world, as 1 Peter does in some detail by focussing on the different contexts in which the addressees may find themselves (slaves in 2:18; wives in 3:1; husbands in 3:7).

Salvation, which is ultimately eschatological (1:3-13), is already operative in the present time among believers: their mortality is overcome by their having been begotten anew by God $(1: 3,23)^{8}$; they are challenged to use their freedom in order to act as servants of God (2:16); their evil desires should be replaced by an ardent desire for the Gospel (2:3: the milk of the Word $)^{9}$ so that they may grow up and become mature in view of their salvation; the sufferings and challenges from their hostile environment should be turned by these believers into a missionary opportunity in order to persuade them to give glory to God $(2: 12,15 ; 3: 1-2,15-16)$. In all of this the letter offers a positive, joyful perspective (see De Villiers 1975) while highlighting the challenges raised by mortality, futile desires and by opposition from society. They are filled with love and joy, because in faith they know the good news of Jesus Christ (1:8-9): 'He himself bore our sins in his body

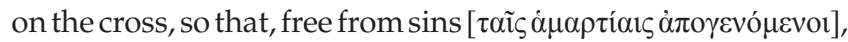
we might live for righteousness; by his wounds you have been healed' (2:24).

Through the proclamation of the gospel the addressees now find themselves in the time of fulfilment (1:10-12), but in this time of fulfilment they find themselves still in an 'in between' situation: their present experience is paralleled by the past sufferings of Christ while the present glory of Christ is their own future - their inheritance held for them in heaven (1:3-5). ${ }^{10}$ This history of salvation is further interpreted more broadly in light of the history and reality of Israel as the people of God (Achtemeier 1996:69-73).

The letter is filled with hope and joy, because the author sees the present sufferings and difficulties within a comprehensive perspective of history and creation (1:3-12). Within this perspective the focus is on the personal and communal

\footnotetext{
$7 .[H]$ ow to be free people and good citizens who nevertheless gave final obedience to God, is then provided in the following verses, and indeed represents a primary to God, is then provided in the following verses, and ind
intention of the letter as a whole' (Achtemeier 1996:187)
}

8.See Senior (2003:31), who points to the active aorist participle in 1:3, which emphasises the action of God: begotten anew and not merely born again

9.It is more likely that $\lambda$ oүıкó $\zeta$ should be seen as referring the life giving Word mentioned a few verses before, 1:23-24 (see Spicq 1966:79-80). Harink (2009:65) comments: 'This milk also abundantly nourishes the intellect. The Logos of God is logikos ('rational'): it feeds thought. Rationality that is both founded and fed by the word of God is rationality in the true sense; it is understanding conformed to the truth of the gospel.' Senior (2003:4) sees it first of all as spiritual and metaphorical milk; but in the end he relates it to the proclaimed message.

10.'In the one set of parallels, Christ's past and the Christians' present are paralleled, and Christ's present and the Christians' future are similarly paralleled. In the second set of parallels, which grows out of the first, the Christians' past is contrasted with their future. In that way the events of Christ's passion become the pattern for the temporal structure of the Christians' life and fate' (Achtemeier 1996:68). transformation to which the addressees are called in the here and now - a transformation which has been made possible for them by God in Jesus Christ. The letter focuses on the present, which is full of hope because of the faithfulness of God the Creator (4:19) and because of Christ who is offered as a firm foundation stone to those who entrust themselves to him (2:6).

While the present is full of hope the believers are, nevertheless, still in the flesh, and still strangers and aliens. ${ }^{11}$ The sufferings and difficulties of believers should not be reduced to verbal abuse, calumny and ostracisation, but these are best understood as including more broadly all the sufferings and difficulties, which are part of life in the flesh. ${ }^{12}$ While being in the flesh is marked by the negativity of weakness, ignorance and darkness, suffering and death, the letter calls for a positive and active response - a response which is modelled after that of Jesus $(2: 20-24 ; 3: 18 ; 4: 1-2,13)$. What this response should be like is well-summarised in 4:19: 'Therefore, let those suffering in accordance with God's will entrust themselves to a faithful Creator, while continuing to do good'13 and in 5:6-7 'Humble yourselves therefore under the mighty hand of God, so that he may exalt you in due time. Cast all your anxiety on him, because he cares for you'.

In their condition in the flesh the faithful should humble themselves under the mighty hand of God, which means they should recognise their nothingness and total dependence on God (1:24). However, this does not amount to total passivity and a withdrawal from the earthly realm, but it requires an understanding of their condition and an active commitment to God, precisely in their present condition, marked by various trials. In other words, they should submit themselves to God, ${ }^{14}$ entrust their difficulties to the care of the faithful Creator and continue to do good in society $(2: 15,20 ; 3: 6,17 ; 4: 19 ; 2: 14) .{ }^{15}$

11.Janse van Rensburg (1998) gives an overview of the discussion whether 'strangers and aliens' should be taken in a socio-political sense or in a theological spiritual sense. He (Janse van Rensburg 1998:580) concludes: 'This label, however, does no merely describe their social position. In the letter the abusive, and in some way derogatory, title is transformed to a proud self-identification by giving it a deepe and theologically positive sense.' In his commentary Elliott (2000:483) concludes: 'In 1 Peter, on the other hand, the issue is the suffering of believers treated as social-cultural strangers and aliens. The encouragement that our author offers is not that the addressees are pilgrims on their way to a heavenly home but that they have already been granted a home in the household of God.' However, this interpretation plays down the eschatological perspective and does not pay sufficient attention to the traditional interpretations of the time. Compare Philo (Conf. 79): 'Therefore, very naturally, Abraham says to the guardians of the dead and to the arrangers of mortal affairs, after he has forsaken that life which is only death and the tomb, 'I am a stranger and a sojourner among you' [Gn 23:4], but ye are natives of the country, honoring the dust and earth more than the soul.' I agree with Achtemeier 1996:71. 'The phrase is therefore not descriptive of the secular political status of the readers, whether before or after their conversion.'

12.These would include amongst the various trials (1:6): mortality (1:24), inner division between the desires of the flesh and the well-being of the soul $(2: 11)$ leading to futile ways (1:18), malice, guile, insincerity, envy and slander (2:1), leading to futile ways (1:18), malice, guile, insincerity, envy and slander $(2: 1)$,
unjust suffering of the slaves at the hands of their masters (2:19), coping with an unjust suffering of the slaves at the hands of their masters (2:19), coping with an
environment full of licentiousness, passions, drunkenness, revels, carousing, and environment full of licentiousness, passions, drunkenness, revels, carousing, and
lawless idolatry (4:3), and of course also the fact that faithfulness to God involves sufferings. Many scholars, however, prefer to interpret the 'various trials' as sufferings resulting from faithfulness to Christ (see Harink 2009:48), but this does not apply to the challenges discussed under 2:13-3:12

13.All English translations from the Bible are from the NRSV.

14.The noun to action: 1:2, 14, 22 (Kittel 1964:224).

15.Doing good is not merely being a law-abiding citizen, but submitting to God's will, which de facto will imply 'exceptional acts of civic responsibility' (Sleeper 1968:283). The ability to do good is the fruit of their re-generation by God; like good trees they then produce good fruit (Spicq 1966:103-104). Growth and fruits good trees they then produce good fruit (Spicq 1966:103-104). Growth and fruits
are commonly seen as work of God, but it requires the right soil on the part of the human beings to let God's Word be fruitful. 
This article will first look at the project of God, the faithful Creator, who established creation as 'flesh', but who also offers the gift of freedom by which human beings are able both to understand their condition by means of the Gospel and to submit to God. By doing so they open themselves to God's generating power and transcend their 'fleshly' state, that is, they are made holy and immortal. A second part will look at the saving role of Christ as the powerful yet rejected stone placed and offered by God as the model and means to transcend the 'flesh' in the flesh (4:1-2). A final part will focus on the new birth and the process of growth.

\section{The project of the faithful creator: Believers are offered a share in God's eternal life and Holiness}

'Therefore, let those suffering in accordance with God's will entrust themselves to a faithful Creator, while continuing to do good' (4:19). ${ }^{16}$ Human beings are seen as utterly limited and mortal; they are flesh (1:24). The most basic contrast in the Bible is that between God the Creator and the whole of created reality, between God who is immortal and the creature who is mortal, between God who is holy and the creature who is impure and sinful. This view is maintained also in 1 Peter. The human condition is one of 'flesh' (weak and mortal) contrasted with the 'living' and 'lasting' Word of God. ${ }^{17}$ However, the created reality is not seen as static and closed in on its present limitations, but it is constituted in a dynamic way, as open to share in the divine life and holiness. In 'a cosmic sweep of history' (Senior 2003:46), the letter situates this openness within the history of created reality, which bears the stamp of Christ from the beginning to its completion (1:20-21). Human beings are called upon to recognise their absolute dependence and nothingness before God, to entrust themselves to God in faith (4:19) and to submit to God in obedience $(1: 2,14,22)$. The fruit of this faith and submission will express itself in a transformation of their lives into mutual love (1:22) and, generally, in good action or conduct (see 2:14, 15, 20; 3:6, 17, 19; 4:19). ${ }^{18}$ Their lives are meant to reflect God's holiness while still in the flesh (4:2). ${ }^{19}$ Those who submit to the Word are on a journey away from their mortal and unholy condition. The expression resident aliens and strangers expresses this potentially transitional condition of human beings and reminds them of the journey out of this condition towards the goal to which they are called: 'If you invoke as Father the one who judges all people impartially according to their deeds, live in reverent fear during the time of your exile' (1:17; see $4: 2)$. The exile is

16.The issue of suffering is prominent in 1 Peter: $\pi$ á $\sigma \chi \omega$ occurs 12 times: $2: 19,20,21$ $23 ; 3: 14,17,18 ; 4: 1(2 x), 15,19 ; \pi \alpha ́ \theta \eta \mu \alpha$ occurs 4 times: $1: 11 ; 4: 13 ; 5: 1,9$

17.'The term 'all flesh' (pasa sarx) refers to the entirety of the human condition with emphasis on mortality, much as it is used in the Pauline tradition (similar uses in $3: 18$ and $4: 1$ in reference to Christ's death and in 4:2, 6 referring to the human condition' (Senior 2003:48). Michaels (1988:78) understands it as referring the fragile and short lived condition of humanity in general or, more specifically here, of the splendour of pagan society.

18.'Doing good' also has a missionary and world transformative aim (Fagbemi 2010).

19.See 1:14-16: 'Like obedient children, do not be conformed to the desires that you formerly had in ignorance. Instead, as he who called you is holy, be holy yourselve in all your conduct; for it is written, "You shall be holy, for I am holy." temporary, even short, and the aim of this exile is the 'testing' and purifying of the faith (1:6-7). The ultimate aim of the journey is:

- ... an inheritance that is imperishable, undefiled, and unfading, kept in heaven for you, who are being protected by the power of God through faith for a salvation ready to be revealed in the last time (1:4-5).

- ... for you are receiving the outcome of your faith, the salvation of your souls (1:9).

In order to understand 1 Peter as much as possible within its cultural background and in order to sensitise ourselves to 'possible meanings' of the text (not 'the' meaning), it will be helpful to keep in mind the writings of Philo ${ }^{20}$ and of early Christian writers. Some passages from Philo reflect on the difference between the Creator and the created and, most importantly, on the way forward from within this condition:

What deadlier foe to the soul can there be than he who in his vainglory claims to himself that which belongs to God alone? For it belongs to God to act, and this we may not ascribe to any created being. What belongs to the created is to suffer, and he who accepts this from the first, as a necessity inseparable from his lot, will bear with patience what befalls him, however grievous it may be. (Cher. 77$)^{21}$

Human freedom is of necessity receptive freedom. Submitting oneself to the hard truth about oneself as 'created', is the way forward:

Know, then, $\mathrm{O}$ excellent man, that God alone is the truest, and most real, and genuine peace, and that every created and perishable essence is continual war. For God is something voluntary, and mortal essence is necessity. Whoever, therefore, is able to forsake war, and necessity, and creation, and destruction, and to pass over to the uncreated being, to the immortal God, to the voluntary principle, and to peace, may justly be called the abode and city of God. (Somn. 2:253)

Human beings have been given this possibility to 'pass over', to transcend the limitations of the creature in order to share in the immortality, holiness and freedom of God instead of remaining chained to creaturely necessity and mortality. However, it is ultimately God's work. Philo links this possibility with the gift of the mind in the human soul which tends to responsibility and freedom:

... for that is the only quality in $\mathrm{us}^{22}$ which the Father, who created us, thought deserving of freedom; and, unloosing the bonds of necessity, he let it go unrestrained, bestowing on it that most

20.The preserved writings of Philo constitute an important body of evidence about Greek speaking Judaism in the first half of the 1 st century CE. We can assume a broad common background between the New Testament writings and Greek speaking Judaism, although the focus of attention for the commonality with Philo has been on Paul, Hebrews and John (Runia 1993:63-86). More recently, Seland $(1995,2005)$ has explored 1 Peter. All quotations from the texts and translations of the works of Philo are taken from BibleWorks 9.

21.Winston (2001:145) quotes from a fragment of Philo's lost fourth book of his Legum Allegoriae, commenting on the famous text of Deuteronomy 30:15 and 19: 'It is happy thing for the soul to choose the better of two choices put forward by the creator, but it is happier not for the soul to choose but for the forward by the Creator, but it is happier not for the soul to choose but for the Creator to bring it over to himelf and improve it.... But when he affirms the first and better principle, God, leaving no work for a created being but showing it to be inactive and passive.'

22.That quality is that of the soul, which is made up of 'a purer and more excellent essence of which the divine natures were formed' (Deus 46). 
admirable gift and most connected with himself, the power,

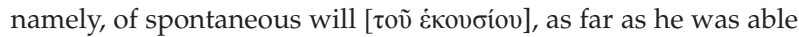
to receive it; for the irrational animals, in whose soul there is not that especial gift tending to freedom, namely, mind, are put under the yoke and have bridles put in their mouths, and so are given unto men to be their slaves, as servants are given to their masters. But man, who has had bestowed on him a voluntary and self-impelling intellect, and who for the most part puts forth his energies in accordance with deliberate purpose, very properly receives blame for the offenses which he designedly commits, and praise for the good actions which he intentionally performs. (Deus 47)

Human beings find themselves in this condition of the flesh, but God has given them also the ability to transcend this condition by means of the 'use of their energies in accordance with deliberate purpose'. These views are not elaborated philosophically in 1 Peter, but we can see how Philo articulates, in more philosophical language, the basic tenets which are also fundamental in 1 Peter. In this sense we can understand also 2:16 and 5:2:

As servants of God, live as free people, yet do not use your freedom as a pretext for evil (2:16)

... to tend the flock of God that is in your charge, exercising the oversight, not under compulsion [àv $\alpha \gamma \kappa \alpha \sigma \tau \tilde{c} \varsigma$ ] but willingly

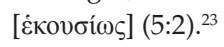

Freedom as willingness to serve God and as human responsibility to give an account to God about one's life (4:5; 1:17) is seen as a gift of sharing - in limited ways - in the divine qualities of immortality, holiness and freedom from necessity. Achtemeier (1996:326) has pointed to the pattern not ... but, which is very common in 1 Peter (see 1:14-15, 18$19,23 ; 2: 18 ; 3: 21 ; 4: 2,12-13) .{ }^{24}$ Some of these texts can best be understood in light of the pattern of the two ways whereby the addressees are challenged to choose, to opt for the lifegiving way in order to reach the goal of that way. ${ }^{25}$ This tradition of challenge to choose and to consent willingly to God's ways is found in a long tradition from Deuteronomy 30:15-20 all the way to the Didache 1-5 and the Epistle of Barnabas 18-21. As Orbe (1970:365) has clearly documented, the pre-Nicene interpretation of Deuteronomy 30:15 and 19 did in no way understand this choice as 'mere indifference or choice between contradictories or contraries', but as a divinely guided saving ascent. ${ }^{26}$

The issue of being freed from necessity and becoming good soil for the Word by submission was a point of particular interest in the Early Church. Justin Martyr, for instance, pointed to the contrast between the two births in terms of the

23.The kind of 'compulsion' envisaged is illustrated in the second antithesis as being possessed by 'sordid gain', while the willingness is further developed as willingness to serve God, and by the second antithesis as 'eagerness' (see Achtemeie 1996:326).

24.According to Achtemeier (1996:326), 'there are no clear parallels to these contrasts elsewhere in the NT, indicating that although tradition may underlie them, it is by no means certain that it does'.

25.The tradition, which seems to have shaped the texts which appear in the context of commands, like 1:14-15; $4: 2$, together with the texts which contrast positive and negative behaviours like 2:1-2 ('rid yourselves ... long for'); 11-12 ('abstain ... conduct yourselves'), can best be understood as shaped by the two ways tradition.

26.See also the text from Philo quoted in footnote 21. contrast between compulsion and ignorance on the one hand and choice and understanding on the other - a contrast we already find in Philo:

Since at our birth we were born without our own knowledge or choice, by our parents coming together, and were brought up in bad habits and wicked training; in order that we may not remain the children of necessity and of ignorance, but may become the children of choice and knowledge, and may obtain in the water the remission of sins formerly committed, there is pronounced over him who chooses to be born again, and has repented of his sins, the name of God the Father and Lord of the universe. ${ }^{27}$

The expression of 1 Peter 5:2, $\mu$ خ̀ $\dot{\alpha} v \alpha \gamma \kappa \alpha \sigma \tau \tilde{\omega} \varsigma \dot{\alpha} \lambda \lambda \lambda^{\prime} \dot{\varepsilon} \kappa o v \sigma i ́ \omega \varsigma$

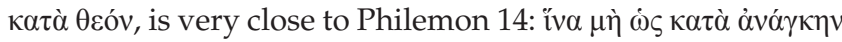

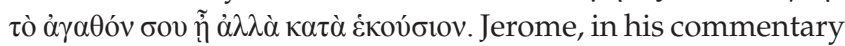
on this expression in Philemon, explains the reasons behind these two stages in God's plan. ${ }^{28}$ Although Jerome lived much later, it must be remembered that it is most likely that he took the whole argument from a now lost commentary of Origen on this verse. According to Decock (2010): $:^{29}$

Jerome first broaches a question raised by some people, as to why God has not created human beings in such a way that they would of necessity do what is good. According to him, God could have created humans in such a way that they would not be able to do evil, but then they would be good by necessity, not voluntarily, and therefore not really good, because: 'Certainly, nothing can really be called good, except if it is voluntary' (411412). Furthermore, in order for us to be similar to God, freedom of choice is required, as God is good by choice, not by necessity. If, however, we had been created good by necessity, we would no longer be similar to God. Therefore, by endowing us with our own free will, God made us more in his own image and likeness. Being like God is absolutely good, while being good by necessity is even in some way an evil (415-420). (pp. 280-281)

In light of our creation as mortals and our calling to freedom, holiness and immortality we can understand how 1 Peter can call for 'submission' to God in our suffering as the way to immortal life: 'Therefore, let those suffering in accordance with God's will entrust themselves to a faithful Creator, while continuing to do good' (4:19).

Human beings are to face their condition with humility and hope. This condition is appropriately described as 'resident aliens and strangers' and as 'in the flesh'. They are to respond to God in this condition by doing good, that is, by using their energies in accordance with the freely chosen purpose of doing God's will: 'so as to live for the rest of your earthly [in the flesh] life no longer by human desires but by the will of God' (4:2). ${ }^{30}$ 27.Justin, 1 Apol. 61 (translation The Ante-Nicene Fathers 1:183, Roberts \& Donaldson 1979).

28.For the text of Jerome's commentary on Philemon, see Bucchi 2003.

29.Similar ideas are found in other texts of Origen: '... that man received the honor of God's image in the first creation, whereas the perfection of God's likeness was reserved for him at the consummation. The purpose of this was that Man should acquire it for himself, by his own earnest efforts to imitate God. In this way, while the possibility of attaining perfection was given to Man in the beginning through the honor of the 'image', even so he should, in the end obtain for himself the the honor of the 'image, even so he should, in the end, obtain for himself the perfect likeness' by the accomplishment of these works' (Origen, Princ. 3.6.1; The Ante-Nicene Fathers 4:344, Roberts \& Donaldson 1979). The material world (and 4.4.8). It is holy when directed by the soul towards God; it is carnal when undirected by the soul to its proper goal (see Thomas 2004).

30.Compare with 2:15; 3:17. 
The will of God must be seen as the whole plan of God, from the creation to its fulfilment $(1: 20)$ in which the present life in the flesh is one stage in God's design of salvation. In that sense it is a necessary stage (1:6). This is the kind of 'necessity' that is also asserted, for instance, in Acts 14:22 and which corresponds to the 'necessity' of the suffering and death of the Christ (Mk 8:31; Lk 9:22). The passage in 1 Corinthians 15:42-58 reflects a similar view of two stages in God's work of creation and salvation, leading from the creation of the first Adam to the second Adam, from imperfection to perfection, from being earthly to being heavenly. The imperfect state must be borne in hope and in submission to God, because it is the way God works:

The first man was from the earth, a man of dust; the second man is from heaven. Just as we have borne the image of the man of dust, we will also bear the image of the man of heaven (1 Cor $15: 47-49)^{31}$

Gnostics could not appreciate 'the man of dust' as having a positive place in God's plan of salvation. They claimed that in view of all this imperfection, injustice and suffering the creator could not be seen as good and faithful. Irenaeus, in reply, articulated what was at least implicit in 4:19: the insistence on the faithful Creator. Irenaeus reaffirmed that God's work with human beings was necessarily a gradual project, from imperfection towards perfection, from infancy to full maturity, from factuality to human cooperation. ${ }^{32}$

Centuries later, Bernard of Clairvaux, who continued the tradition of the Church Fathers, summarises the whole of salvation as a process of four stages in the transformation from imperfect love towards the perfection of love of God (De Diligendo Deo 15). ${ }^{33}$ The first stage is very earthly, mere love of self. Bernard refers to 1 Corinthians 15:46, in which he sees a divine design, beginning from the flesh and leading towards perfection. In this passage he also recalls Psalm 33:9 (MT 34:8) to mark the transition from the second to the third degree of love, a text which, in 2:3, also functions to evoke the progress in the transformation process. ${ }^{34}$ In 1 Peter, as in Bernard, 'tasting the goodness of the Lord' is a form of profound understanding and appreciation which results in a strong desire for the 'milk of God's Word' (2:2). It is this Word that regenerates $(1: 23)^{35}$ and that leads to ever more genuine love (Bernard) or, as 1 Peter develops it, which generates holiness of life (1:14-15) and 'fervent love' (1:22).

31.Commentators commonly contrast this order with Philo's view of the order: first the heavenly and then the earthly (Barrett 1971:374-375; Murphy-O'Connor 1990:813-814).

32.See for example Irenaeus, Haer. 4:38 (text in Rousseau et al. 1965:942-961). The whole chapter deals with the question why God did not create human beings in a
perfect state from the beginning. The answer of Irenaeus is that human beings are perfect state from the beginning. The answer of Irenaeus is that human beings are
'created? beings. Therefore, they are imperfect and mortal, but by God's free gift 'created]? beings. Therefore, they are imperfect and mortal, but by God's free gift
they can with time acquire the power of the Uncreated and become immortal. What is required is submission to God, which involves the commanding action of the Father, the executing and modelling action of the Son and nourishing and fostering action of the Spirit. For more texts on Adam (the first man) and Christ (the perfect man) in Irenaeus, see Daniélou (1960:30-47).

33.In the edition by Leclercq \& Rochais (1963:138-144).

34.'Finally, these verses [2:1-3] extend the image of birth and family by advancing the focus from birth to growth towards salvation, an idea with both personal and communal implications' (Elliott 2000:405).

35.Compare with Philo, Fug. 97: 'Therefore he exhorts him who is able to run swiftly to strain onwards, without stopping to take breath, to the highest word of God which is the fountain of wisdom, in order that by drinking of that stream he may find everlasting life instead of death.'
God's work of salvation in 1 Peter can be seen as a progressive history, which started before the creation of the world (1:20) and will be completed at the end with the revelation of Jesus Christ $(1: 5,7)$. This initial condition of the creatures is carnal: the creature is mortal, weak, prone to sin and de facto sinful. The second stage, the stage at which the addressees find themselves at present, was initiated by the birth from the 'living and enduring word of God' in baptism as the inauguration of their life in faith (1:23). At this stage they still experience the weakness of the flesh, but they can look forward to a future free from death, moral impurity and decay (1:4). In this sense they already share in the qualities of God beyond the capabilities of the 'creature'.

The model and means of this transformation is the death and resurrection of Jesus Christ (1:3, 21; 2:6, 21-25; 3:18-25; 4:13; $5: 1,10)$. Jesus Christ is God's gift to humanity. One image used in the letter is that of the living stone that God has 'placed' and to whom the believers are invited to come in order to become themselves living stones of a spiritual house, ${ }^{36}$ a holy priesthood, to offer spiritual sacrifices (2:4-5). These spiritual sacrifices are the good actions of the believers living in the world (2:11-12), which will have, as they hope for, the effect that the Gentiles will glorify God. What this good behaviour entails, is explained in section 2:11-3:12 of which 2:11-12 forms the introduction, and in subsequent sections (Combrink 1975:43, 55-57).

\section{Christ the living stone $(2: 4-10)^{37}$}

In 2 Corinthians 8:9 Jesus Christ left his previous state of wealth in order to take on a state of poverty; in John 1:14-18 he left his position close to the Father's heart in order to become flesh. In 1 Peter, Jesus is 'placed' by God as the living stone of a new or a renewed building in Zion (2:6). The image suggests something powerful, a stone, even a rock (2:8). However, he shares the vulnerability of the flesh (1:24) and is rejected (2:6-7), but afterwards the stone is vindicated as 'a cornerstone chosen and precious'. The believers are challenged to approach it. It is in fact a participation ${ }^{38}$ in the

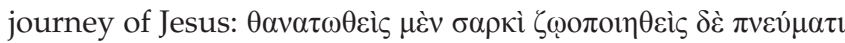
(3:18). ${ }^{39}$ The saving power of Christ, the corner stone of the newly constituted people, shapes the believers into the shape

36. Elliott (2000:115) stresses the social and psychological dimension of the emphasis on the 'house': 'In this contrast of homelessness and 'at-home-ness', the concept of the household of God serves as a potent symbol socially, psychologically, and religiously for addressing the predicament of social estrangement and for integrating the experiences of life and the expressions of faith.'

37.Jesus, as the corner stone or the cap stone, is found in a variety of New Testament passages besides 1 Peter: Matthew 21:42-45; Mark 12:10-11; Luke 20:17-18; Romans 9:32-33 as well as in Barn. 6.

38.According to Achtemeier (1996:251), 'it is the uniqueness of Christ's representative death that is emphasized in this passage, and while it is true that the Christians relationship to Christ shows them the way they must live, the ethical aspects of that relationship are not brought to the fore in this verse ...' (similarly De Villiers 1975:78). However, as Bigg (1902:161) already pointed out, the point is made clear in $4: 1$ and following. The encouragement is not merely that Christians share Christ's victory, but that they can face the suffering with hope.

39.I take the datives as indicating the sphere of existence: with regard to the flesh indicates then the earthly life of Jesus subject to mortality; in this condition he suffered and was put to death; he shared our human condition of weakness and mortality; in this condition he suffered for the sins of the wicked although he was just. He was brought to life, a life in the realm of the Spirit, the realm of fullness of life, of holiness. For other interpretations, see Achtemeier (1996:250-251). He life, of holiness. For other interpretations, see Achtemeier (1996:250-251). He
himself in the end opts for a dative of agency: 'put to death by unbelieving humanity, but raised by (God's) Spirit' (Achtemeier 1996:250). 
he himself has given to his own earthly life: in the condition of the flesh with its weakness and suffering he lived a holy life. That the believers become 'living stones' by being joined to him suggests that they share in the solidity and resilience of the original living stone and are empowered to overcome sin and to bear the fruit of holy lives. ${ }^{40}$ It is not a case of merely enduring suffering, but of overcoming sin and leading a holy life while in the flesh. This sinlessness and holiness of Jesus in spite of the trials is regularly emphasised:

- ... as a lamb without defect and blemish (1:19).

- 'He committed no sin, and no deceit was found in his mouth'. When he was abused, he did not return abuse; when he suffered, he did not threaten; but he entrusted himself to the one who judges justly. He himself bore our sins in his body on the cross, so that, free from sins, we might live for righteousness; by his wounds you have been healed (2:22-24).

- For Christ also suffered for sins once for all, the righteous for the unrighteous, in order to bring you to God (3:18).

- Since therefore Christ suffered in the flesh, arm yourselves also with the same intention (for whoever has suffered in the flesh has finished with sin), so as to live for the rest of your earthly [in the flesh] life no longer by human desires but by the will of God (4:1-2).

In this Jesus Christ is both the 'exemplar and enabler' (Elliott 2000:110) for the believers, that is, for those who have armed themselves with the same 'intention' or the same 'way of approaching' life. ${ }^{41}$ By being joined in this way to Christ, the living stone, they become members of God's people constituted in a new way; they become a spiritual temple, a holy priesthood offering spiritual sacrifices (2:4-10). The spiritual sacrifices of the holy priesthood are understood as their holy conduct: ${ }^{42}$

Like obedient children, do not be conformed to the desires that you formerly had in ignorance. ${ }^{43}$ Instead, as he who called you is holy, be holy yourselves in all your conduct; for it is written, 'You shall be holy, for I am holy' (1:14-16). ${ }^{44}$

However, while Christ is the model and means of a holy life in the present condition in the flesh, the final goal is to share also in the glory of the risen Christ:

And after you have suffered for a little while, the God of all grace, who has called you to his eternal glory in Christ, will himself restore, support, strengthen, and establish you. (5:10)

40.That Christians are living stones in this context must be understood in relationship to Christ, the living stone, whom God has placed as source of life. It is God who phe perame living stones. The purpose is that they should become a holy priesthood offerin spiritual gifts (2.5), which, according to Achtemeier (1996:156), ', includes 'witness power of witness (as made explicit in 2:11-12).

41.Selwyn (1947:208) explains Ěvvotav as, 'principle of thought and feeling'. He points to the use of the word in Philo, Praem. 42 and Hebrews 4:12. It is 'Christ's way of thinking .... on an ethical level' (Senior 2003:114). Compare with Toṽ

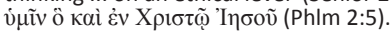

42.'This kind of conduct is distinctive, defensive, and attractive. It distinguishes believers from non-believers (1:14-16; 4:2-4), it refutes suspicions and charges of wrongdoing (2:15), and it can lead detractors themselves to join believers in the glorification of God (2:12; 3:1-2)' (Elliott 2000:116).

43.This behaviour is detailed a little more in a later verse: 'You have already spent enough time in doing what the Gentiles like to do, living in licentiousness, passions, drunkenness, revels, carousing, and lawless idolatry' (4:3).

44.The noun $\alpha \dot{v} \alpha \sigma \tau \rho \circ \varphi \eta$ and the corresponding verb occur a number of times and display the letter's focus on holiness of conduct (1:15); holiness like that of God: $1: 17 ; 1: 18 ; 2: 12 ; 3: 1,2,16$. The theme of 'purification' in 1:22 also further emphasises the aspect of moral conduct.
By his great mercy he has given us a new birth into a living hope through the resurrection of Jesus Christ from the dead ... (1:23)

This brings us to the issue of the new birth.

\section{Begotten anew}

In contrast with the mortal and passing condition of the flesh, believers are begotten anew of the imperishable Word of the Gospel (1:23-25). The theme of a new birth ${ }^{45}$ was already announced at the beginning of the letter:

By his great mercy he has given us a new birth into a living hope through the resurrection of Jesus Christ from the dead, an inheritance that is imperishable, undefiled, and unfading, kept in heaven for you, who are being protected by the power of God through faith for a salvation ready to be revealed in the last time. (1:3-5)

The letter is focussed on the present time, the time between the event of the new birth (baptism) ${ }^{46}$ and the full inheritance of glory (1:13-15). ${ }^{47}$ This birth is the beginning of a process, a seed that must be tended and which will find its maturity and fulfilment in the future, 'when Jesus Christ is revealed' $(1: 7){ }^{48}$ While the inheritance lies in the future the present challenge to the addressees is that as new born children they have to grow to full maturity. It is significant that in terms of the imagery of a birth, the seed is specified as the living and enduring Word of God, and more precisely, the good news proclaimed to them $(1: 23,25)$. According to 1 Peter the central issue of the gospel is that God has 'placed' or 'given' (2:6) Jesus Christ as their solid cornerstone, and his innocent life and death are the way to the resurrection that all are called to walk (2:21). It is this Word of God, this gospel, this memory of Jesus Christ, this mind of Christ that reshapes the lives of the addressees (1:25). They are compared to infants who need to be fed with milk, but the milk they need is

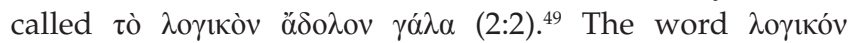
suggests that this milk consists of both word (of God) and reason (sound reason in accord with the Word of God). ${ }^{50}$

45. While the image of the seed focuses on the aspect of generation rather than the aspect of birth, the two obviously cannot be separated. The NRSV maintained the language of birth, probably because birth can be taken in its broader sense including generation, being borne in the womb and being delivered.

46.There is some disagreement amongst interpreters whether the 'new birth' refers to baptism. Senior (2003:48) holds that: 'it is likely that the author refers to the entire inaugural experience of the Christian, one rooted in God's own act of salvation, signified in the baptismal ritual of initiation and expressed in a transformed moral life'. Achtemeier (1996:139) may be making too much of the transformed moral life'. Achtemeier (1996:139) may be making too much of the
distinction between rebirth and rebegetting if we keep texts like Justin (1 Apol. 61)

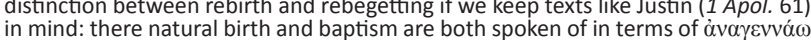
(PG 6:421A).

47.We find in 1:13-15 a reference to the past ('the desires that you formerly had in ignorance'), the present ('Therefore prepare your minds for action; discipline yourselves; set all your hope on the grace that Jesus Christ will bring you when he is revealed. Like obedient children, do not be conformed to the desires that you formerly had in ignorance. Instead, as he who called you is holy, be holy yourselves in all your conduct') and the future ('the grace that Jesus Christ will bring you when he is revealed').

48.The growth of the seed, as the growth of a person to maturity, is a mysterious process and is in God's hand (Mk 4:26-29). At the same time, human receptivity is crucial (Mk 4:1-20). James 1:21-27 speaks about the word that is implanted and has the power to save their souls, but he insists that they need to be not merely hearers of the word but doers. 1 Peter fully agrees with that; the frequency of the phrase doing good is one indication of this $(2: 14,15,20 ; 3: 6,17 ; 4: 19)$.

49.Philo sees the milk as the symbol of the encyclical sciences, which are merely preparing for the fuller gift of the virtues (see Congr. 19). Paul considers the milk as very elementary food adapted to those who are still fleshly (1 Cor 3:2). The word ö $\delta 0 \lambda$ os suggests moral uprightness in contrast with $\delta \delta^{\prime}{ }_{0} \mathrm{c}_{\text {, }}$ which occurs in 2:1, 22; 3:10.

50.This is also the argument in 4 Maccabees about 'devout reason,' which is understood as reason guided by the Law $(1: 13-18 ; 18: 1-2)$. 
In other words, not unlike 1 Corinthians 1:17-31, the addressees are encouraged to absorb within their lives the wisdom of God revealed in Jesus, crucified and risen. This new birth is only a beginning; the new life must be nourished and mature (Wilkins 1997:793). Its constant nourishment by means of the gospel liberates from ignorance (1:14), develops a new mind (1:13) and a new way of thinking (4:1). This birth is not mere theoretical insight, but it must 'realise' itself in a way of living and therefore requires a decisive turning away from vice. According to 2:1-2 the desire for that kind of milk must go hand in hand with moral reform by getting rid of vices. Furthermore, for the desire to develop they need to have tasted the goodness of the Lord (2:3). This tasting from Psalm 33:9 (LXX; also see MT 34:8) in 2:3, as we have seen, is a text which was understood in the Christian tradition as referring to experiential knowledge of God's work in one's life and which stirs up even greater desire. ${ }^{51}$ Fika Janse van Rensburg's interpretation (2009:108) of the syntactic structure confirms this by highlighting the link between the 'tasting' and the 'desire' of 2:2. This new understanding involves obedience to God's Word and trust in Christ's covenant blood (1:2). ${ }^{52}$

In order to understand the generating power of the Word of God, it may be fruitful to pay attention to some texts of Philo, which refer to the generating power of wisdom. He probably expresses, in his own more sophisticated way, an understanding common in his Jewish community about the educational and life-giving power of God's Word or God's Wisdom:

We say, therefore, without paying any attention to the difference here existing in the names, that wisdom, the daughter of good, is both male and a father, and that it is that which sows the seed of, and which begets learning in, souls, and also education, and knowledge, and prudence, all honorable and praiseworthy things. (Fug. 52)

The opposite kind of birth is the one mentioned in James 1:

But one is tempted by one's own desire, being lured and enticed by it; then, when that desire has conceived, it gives birth to sin, and that $\sin$, when it is fully grown, gives birth to death. $(v .14,16)$

There are therefore two possibilities, either to let the soul be ruled by one's own desires or let it be educated by the Word of God as revealed in the gospel. The one leads to life, the other to death. In this way two groups of human beings are constituted based on each one's human response. For those who open themselves to God's Word the creature is given a share in God's holiness and immortality. Those who abandon themselves to their carnal desires are alienated

51.Janse van Rensburg (2009:108) has explored the imagery of the milk given to the newly born, which he identifies as colustrum: 'Having tasted the colostrum they now know that the Lord is good. This experience of the goodness of the Lord becomes the reason why they must yearn for more milk. The milk they are urged to yearn for, is no longer colostrum, which, as part of the birth-process (i.e. as part of the process through which God has saved them), was for their initial sustenance. Rather the milk they should now yearn for is the 'unadulterated milk of God's word', which will make them grow up in their salvation.'

52.A number of scholars have recognised here a reference to Exodus 24:7-8 where the promise of obedience is followed by the sprinkling of the covenantal blood (Achtemeier 1996:88-89; Senior 2003:26-27; Spicq 1966:42-43: 'Thus the end point of election includes both obedience to the Gospel and membership in the new covenant people.') from God and miss out on the gifts of holiness and life, and end in death. These latter have failed to turn to the fountain of life..$^{53}$ As in Deuteronomy 30:15-20 the Law of Moses offers to the Israelites this fountain of life. The offer requires understanding and appreciation of the gift and submission to God.

For 1 Peter the human problem is not so much with the fleshly desires in themselves as with the quality of the soul. The fleshly desires, being what they are, are unable to appreciate God's guidance. The direction must come from a soul, which is instructed by God's Word and which is modelled after the example of Jesus Christ - in other words, which has been reborn. ${ }^{54}$

Whether the tension in 2:11 is between the soul and the body, ${ }^{55}$ or within the soul between the higher part and the lower part, as in Philo, ${ }^{56}$ is not clear, but the important point is that the tension is meant to be resolved by the submission to God's Word. This seems to be what Paul points out about

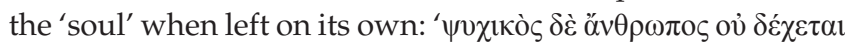

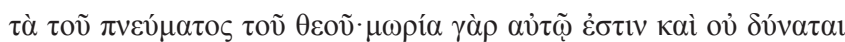

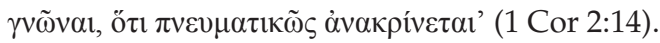

If we compare 1 Peter to Paul, we can say that the rebegetting and maturation take place as the soul is shaped by the mind of Christ (1 Cor 2:16). ${ }^{57}$ It then becomes $\pi v \varepsilon v \mu \alpha \tau \iota \kappa o ́ \varsigma$ instead of

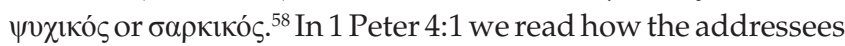

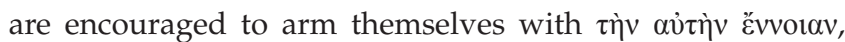
which motivated Christ in his sufferings in the flesh. The image of struggle was also used in 2:11, which speaks of the struggle of the fleshly desires against the $\psi v \chi \eta$. According to Schweizer, $\psi v \chi \eta$ ' 'takes the place that is occupied by $\pi v \varepsilon \tilde{\mu} \mu \alpha$ in Paul (Gl. 5:17)' (1974:653). Indeed, the soul here is the reborn soul, shaped by the good news of Jesus Christ and stirred up by desires which resists the fleshly desires: '... he himself

53 Philo (Fug 198-199) describes the option of this second group as follows: is something more than life; he is, as he himself has said, the everlasting fountain of living [Jr 2:13]. But the wicked having fled away, and having passed their time without ever tasting the draught of immortality, have digged, insane persons that without ever tasting the draught of immortality, have digged, insane persons that
they are, for themselves, and not first for God, having preferred their own actions they are, for themselves, and not first for God, having preferred their own actions
to the heavenly and celestial things, and the things which proceed from care to to the heavenly and celestial things, and the things which proceed from care to
those which are spontaneous and ready.'

54.As Jacob (1974:630) points out about the general Old Testament view: Flesh and spirit 'are not irreconcilable, for God who has made man of corruptible matter also does all that is needed to transfer something of His strength to man. Flesh and spirit are incompatible only when flesh forgets to trust in the God who is Spirit and trusts in itself'.

55.As proposed by Schweizer (1974:653): '2:11 is the most strongly Hellenised $\Psi u x$ ' passage in the NT. ... It thus seems to be a part of man, the flesh being another part'.

56.Philo (Conf. 1:21) recognises different parts in the soul, a higher and a lower, or

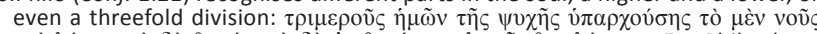

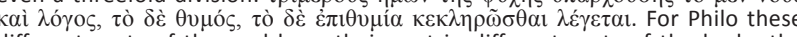
different parts of the soul have their seat in different parts of the body: the rational in the head or heart, the spirited part in the chest, and the lustful in the belly. It is the higher part, which is able to know God and communicate with God. See Seland (2005:122-123) for a brief survey of the different divisions of the soul.

57.Philippians 2:5 and 12-13 refer to that work of God in the soul whereby God shapes the person's thinking, outlook and behaviour. Hawthorne (1983:100) concludes his discussion of these verses by quoting J.H. Michael (1924): 'An effective divine energy is at work in the community and if the Philippians only avail themselves of its presence, cooperate with it, and permit it to express itself in their working, the inevitable result will be not only the willing, but also the achieving, by working, the inevitable result will be not only the willing, but also the achieving, by
them of the salvation of the community.' Hawthorne (1983:99) sees this salvation them of the salvation of the community.' Hawthorne (198
in a non-eschatological sense as its spiritual well-being.

58.1 Corinthians 3:1-3 switch to fleshly as the contrast with spiritual, while 2:14 used 廿uxเкós. 
bore our sins in his body on the cross, so that, free from sins, we might live for righteousness' $(2: 24) .{ }^{59}$

It is important to note that 2:1 continues in $2: 2$, where the emphasis is not merely on living for righteousness, but on right conduct among the Gentiles as a missionary witness to them: 'Conduct yourselves honorably among the Gentiles, so that, though they malign you as evildoers, they may see your honorable deeds and glorify God when he comes to judge'.

The remainder of the letter from 2:13 onwards discusses what this honourable conduct entails in a variety of contexts: while among the Gentiles, while still in this world of the flesh with its limitations and challenges, and with its suffering and persecution.

\section{Conclusion}

1 Peter opens the minds of the addressees to the crucial value of the present time for their salvation $(1: 10-12,18-21)$ by situating it within a comprehensive framework, a grand vision, between the creation of the world (1:20) and the time of final salvation (1:5). This present time is decisively marked by God's action, by the fact that God has placed a precious stone in their midst as their means of salvation (1:4-8). The rejection and vindication of that stone established the pattern for the way to salvation. Jesus Christ shared human weakness and suffering, but did not succumb to sin. He became the precious cornerstone, the means and model of salvation for all (2:21-25). The vision goes together with the challenge to approach that stone by means of faith in this Good News, to let a strong desire for this 'milk' turn us away from the 'fleshly' desires. The addressees are reminded that they have been begotten anew by this Word of the Good News and that the challenge is now to grow into adulthood towards the eschatological salvation (2:2). Three aspects of this growth towards maturity are identified in this article: from the necessity of ignorance to the freedom of joyful faith (1:8-9); from the compulsion of evil desires to eager submission $(2: 16 ; 5: 2)$; and from wicked ways $(2: 1,11)$ toward holiness of life (1:14-17). Finally, it makes all transformations complete on the last day, from mortal existence to 'an inheritance that is imperishable, undefiled, and unfading, which is kept in heaven' (1:4).

\section{Acknowledgements Competing interests}

The author declares that he has no financial or personal relationships which may have inappropriately influenced him in writing this article.

59.Some texts from Philo (Conf. 22 ) may again help us to imagine aspects of the thinking in that context: 'The greatest evil is when all parts of the soul are victims to sin: "For the heaviest of all evils, and almost the only one that is incurable, is the unanimous energy of all the parts of the soul agreeing to commit sin, not one of the parts being able to act with soundness (just as is the case in an evil affecting the whole people), so as to heal those that are sick."' Liberation takes place when the higher part of the soul, the mind, is open to God's mind and is able to bring higher part of the soul, the mind, is open to God's mind and is able to bring everything together under God: 'For you will perceive that there is a mind in you and in the universe; and that your mind, having asserted its authority and powe over all the things in you, has brought each of the parts into subjection to himself. In like manner also, the hind of the universe being invested with the supremacy, governs the world by independent law and justice, having a providential regard not only for those things which are of more importance, but also for those which appear to be somewhat obscure' (Migr. 186 ).

\section{References}

Achtemeier, P.J., 1996, 1 Peter, Fortress, Minneapolis. (Hermeneia).

Alexander, P.H., Kutsko, J.H., Ernest, J.D., Decker-Lucke, S.A., \& Petersen, D.L., (eds.), 1999, The SBL Handbook of style for Ancient Near Eastern, Biblical, and Early 1999, The
Christian studies, Hendrickson, Peabody, MA.

Barrett, C.K., 1971, The First Epistle to the Corinthians, 2nd edn., A \& C Black, London (Black's New Testament Commentaries).

Bigg, Ch., 1902, A critical and exegetical commentary on the epistles of St. Peter and St. Jude, 2nd edn., T\&T Clark, Edinburgh (ICC).

Bucchi, F., 2003, Commentarii in epistvlas Pavli apostoli ad Titvm et ad Philemonem: S. Hieronymi presbyteri opera, Pars I, Opera exegetica 8, Brepols, Turnhout. (CChr.SL 77C). Combrink, H.J.B., 1975, 'The structure of 1 Peter', Neotestamentica 9, 34-63.

Daniélou, J., 1960, From shadows to reality: Studies in biblical typology, Burns \& Oates, London.

Decock, P.B., 2010, 'The reception of the Letter to Philemon in the Early Church: Origen, Jerome, Chrysostom, and Augustine,' in D.F. Tolmie (ed.) Philemon in Perspective: Interpreting a Pauline Letter, pp. 273-287, Walter de Gruyter, Berlin (Beihefte zur Zeitschrift für die neutestamentliche Wissenschaft und die Kunde der älteren Kirche, 169).

De Villiers, J.L., 1975, 'Joy in suffering in 1 Peter', Neotestamentica 9:64-86.

Elliott, J.H., 2000, 1 Peter: A new translation with introduction and commentary, Doubleday, New York. (Anchor Bible Commentaries 37 B).

Fagbemi, S.A.A., 2010, 'Transformation, proclamation and mission in the New Testament: Examining the case of 1 Peter', Transformation 27(3), 209-223.

Harink, D., 2009, 1 \& 2 Peter, SCM, London. (SCM Theological Commentary on the Bible).

Hawthorne, G.F., 1983, Philippians, Word Books, Waco, Texas. (Word Biblical Commentary, 43).

Jacob, E., 1974, ' $\Psi$ uxn', $\kappa \tau \lambda$ ', in G. Kittel \& G. Friedrich (eds.), Theological dictionary of the New Testament, vol. 9, pp. 608-631, Eerdmans, Grand Rapids.

Janse van Rensburg, F., 1998, 'Christians as 'resident and visiting aliens': Implications

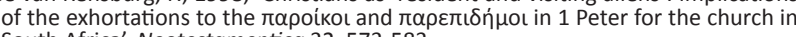
South Africa', Neotestamentica 32, 573-583.

Janse van Rensburg, F., 2009, 'The Referent of Egeusasthe (You have tasted) in 1 Peter 2:3', Acta Theologica 29(2), 103-119.

Jones, F.S., 1992, 'Freedom', in D.N. Friedman (ed.), The Anchor Bible Dictionary, vol. 2, pp. 855-859, Doubleday, New York.

Justin, St., 1884, 'Apologia prima pro Christianis', in J.P. Migne (ed.), Patrologia Graeca (PG), 6, 327-440, Paris.

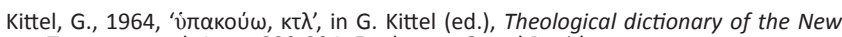
Testament, vol. 1, pp. 223-224, Eerdmans, Grand Rapids.

Leclercq, J. \& Rochais, H. (eds.), 1963, S. Bernardi opera, vol. 3, Tractatus et opuscula, Editiones Cistercienses, Rome.

Michael, J.H., 1924, 'Work out your own salvation', Expositor 9th series, 12, 439-450. Michaels, J. R., 1988, 1 Peter, Word Books, Waco, TX (Word Biblical Commentary, 49).

Murphy-O'Connor, J., 1990, 'The First Letter to the Corinthians', in R.E. Brown, J.A. Fitzmyer \& R.E. Murphy (eds.), The new Jerome biblical commentary, pp. 798-815, Geoffrey Chapman, London.

Orbe, A., 1970, 'El dilemma entre la vida e la muerte: Exegesis prenicena de Deut $30,15,19$, [The dilemma between life and death: The pre-Nicene exegesis of Dt 30:15, 19], Gregorianum 51, 305-365, 508-536.

Roberts, A. \& Donaldson, J. (eds.), 1979, The Ante-Nicene Fathers, 1885-1887, 10 vols. Reprint, Eerdmans, Grand Rapids, Mich.

Rousseau, A., Hemmerdinger, B., Doutreleau, L. \& Mercier, Ch., (eds.), 1965, Irénée de Lyon: Contre les hérésies, Livre IV, édition critique d'après les versions arménienne et latine, Cerf, Paris. (Sources chrétiennes 100/2).

Runia, D.T., 1993, Philo in Early Christian Literature: A Survey, Van Gorcum, Assen. (CRINT III/3).

Seland, T., 1995, 'The common priesthood of Philo and 1 Peter: A Philonic reading of 1 Peter 2:5,9', Journal for the Study of the New Testament, 57, 87-119.

Seland, T., 2005, Strangers in the light: Philonic perspectives on Christian identity in 1 Peter, Brill, Leiden. (Biblical Interpretation Series 76).

Selwyn, E.G., 1947, The First Epistle of Peter: The Greek text with introduction, notes and essays, McMillan, London.

Senior, D.P., 2003, 1 Peter, Liturgical Press, Collegeville (Sacra Pagina).

Schweizer, E., 1974, ' $\psi u x \eta ́$, $\kappa \tau \lambda$ ', in G. Kittel \& G. Friedrich (eds.), Theological dictionary of the New Testament, vol. 9, pp. 637-656, Eerdmans, Grand Rapids.

Sleeper, C.F., 1968, 'Political responsibility according to 1 Peter', Novum Testamentum 10(4), 270-286.

Spicq, C., 1966, Les Épitres de Saint Pierre, Gabalda, Paris. (Sources Bibliques).

Thomas, S., 2004, 'Anthropology', in J.A. McGuckin (ed.), The Westminster handbook to Origen, Westminster John Knox, Louisville, pp. 53-58. (Westminster Handbooks to Christian Theology).

Wilkins, M.J., 1997, 'New Birth', in R.D. Martin \& P.H. Davids (eds.), Dictionary of the later New Testament \& its developments, pp. 792-795, Intervarsity Press, Downers Grove, IL.

Winston, D., 2001, 'Freedom and determinism in Philo of Alexandria', in G.E. Sterling (ed.), The Ancestral Philosophy: Hellenistic Philosophy in Second Temple Judaism: Essays of David Winston, pp. 135-150, Brown Judaic Studies, Providence. (Brown Judaic Studies, 331 - Studia Philonica Monographs, 4). 